\title{
EHMTI-0231. Headache as primary symptom in the neurological emergency department - epidemiological data analysis
}

\author{
A Liverezas* , I Stavropoulos, D Athanasopoulos, S Tsiara \\ From 4th European Headache and Migraine Trust International Congress: EHMTIC 2014 \\ Copenhagen, Denmark. 18-21 September 2014
}

\section{Introduction}

Headache is one of the most common neurological symptoms that lead patients to the ED. The latest data show that $50-75 \%$ of adults globally, have experienced headache at least once during the past year and about $1-4 \%$ can be affected for several days per month, resulting in a huge disease load that increases the cost of health care worldwide.

\section{Aim}

To present data regarding patients that visited the Neurological Emergency department (NED) of General Hospital of Athens "GNA G. Gennimatas" with headache as primary complaint and analyze the demographic, qualitative and quantitative characteristics of them.

\section{Method}

We analysed the data of the patients that visited the NED from $1 / 12 / 2012$ to $1 / 10 / 2013$. Data analysis was based on age, sex, medical history, type of headache, management, red flags and cost. Patients with more major complaints or insufficient data were excluded.

\section{Results}

8045 patients were examined and 1232 presented with headache (15.3\%). 63.9\% were female and this percentage was similar in all age groups. The most common primary headaches were migraine followed closely by tension headache. The prevalence of secondary headaches was $15.9 \%$ and $32.65 \%$ of these had red flags. The total cost of the basic laboratory and imaging investigations is estimated 67653.4 euros.

Neurology, General Hospital of Athens "G.Gennimatas", Athens, Greece

\section{Conclusions}

The majority of headaches in NED are primary. Red flags are important risk factors for secondary headaches. The clinicians ability to recognize the headache type could reduce the economical cost.

No conflict of interest.

Published: 18 September 2014

doi:10.1186/1129-2377-15-S1-D37

Cite this article as: Liverezas et al:: EHMTI-0231. Headache as primary symptom in the neurological emergency department - epidemiological data analysis. The Journal of Headache and Pain 2014 15(Suppl 1):D37.
Submit your manuscript to a SpringerOpen ${ }^{\circ}$ journal and benefit from:

- Convenient online submission

- Rigorous peer review

- Immediate publication on acceptance

- Open access: articles freely available online

- High visibility within the field

- Retaining the copyright to your article

Submit your next manuscript at $\boldsymbol{~ s p r i n g e r o p e n . c o m ~}$ (c) 2014 Liverezas et al; licensee Springer. This is an Open Access article distributed under the terms of the Creative Commons Attribution License (http://creativecommons.org/licenses/by/2.0), which permits unrestricted use, distribution, and reproduction in any medium, provided the original work is properly cited. 